\title{
Analysis on the Development Strategy of Cross-border E-commerce in Yiwu City against the Background of "The Belt and Road"
}

\author{
SHEN Yuting ${ }^{1, a}$, WANG Ying ${ }^{2, b,{ }^{*}}$ and YANG Xiaohui ${ }^{3, c}$ \\ ${ }^{1}$ Hohai University Changzhou Compus, Xinbei District, Changzhou, Jangsu Province, China \\ aguniver@qq.com, b767247770@qq.com, c2773354548@qq.com \\ ${ }^{*}$ Corresponding author
}

Keywords: The Belt and Road, Yiwu City, Cross-Border Electronic Commerce, SWOT

\begin{abstract}
The Belt and Road" is an important strategic plan of China, As the world's "small commodity capital" and a pilot for comprehensive reform of international trade, Yiwu is seizing the strategic opportunity of the "Belt and Road" Initiative, and actively taking the initiative. In particular, it has made major breakthroughs in cross-border e-commerce innovations. It has been approved to establish Zhejiang (Yiwu) cross-border e-commerce innovation and development demonstration zones, and actively develops provincial-level cross-border e-commerce public overseas warehouse pilot sites. This article will analyze the status quo, existing problems and challenges of cross-border e-commerce development in Yiwu from four aspects: strengths, weaknesses, opportunities, and challenges, and make brief suggestions.
\end{abstract}

\section{Introduction}

Thanks to the globalization and development of Internet technology, the e-commerce industry has developed rapidly, breaking through the boundaries of traditional business trade in time and space, changing the traditional trade operation mode and means, shortening the trade cycle, and promoting the development of global economy, and become an important force in promoting the development of the " The Belt and Road". Cross-border e-commerce, as the "Online Silk Road" in the "Belt and Road" initiative, effectively helps countries and regions along the "One Belt and One Road" integrate resources and strengthen economic and trade by trading with a new transaction model and new economic growth point, in order to achieve mutual benefit and common development. Yiwu, as the world's "small commodity capital" and a pilot for comprehensive reform of international trade, grabs the "Belt and Road" strategic opportunity to take the initiative. The country's only privately-owned China-EU class, Yixinou, has opened up closer cooperation with countries along the "Belt and Road" and has brought a lot of tourists. At present, Yiwu is striving to create a "bridgehead" for global consumer goods to enter China and form a new pattern of "buying the world and selling the world".

This research uses the SWOT method to analyze the cross-border e-commerce strategy in the process of Sino-European trade in "The Belt and Road" context and proposes targeted propose.

\section{Organization of the text}

\subsection{Advantages}

\subsubsection{Location Advantage}

Yiwu City, Zhejiang Province is located in the Yangtze River Delta Region where e-commerce is developed. First of all, it is closed to Shanghai, Hangzhou, Ningbo and other economically developed regions, which is conducive to the transfer of information, access to high-tech talent resources, and improve the level of e-commerce production and service. Secondly, convenient transportation and logistics development. Yiwu City is located in the eastern economic zone and has developed railways, highways, and air transportation routes. The opening of the Yi-Shin-Europe 
Railway has greatly promoted the trade between Yiwu City and Europe. What's more, it is next to Ningbo-Zhoushan Port which open the international shipping routes for cross-border e-commerce.

\subsubsection{Foreign trade continues to grow}

According to the statistics of Yiwu Electric Business Office, in 2014, Yiwu had a total export value of 13.71 billion U.S. dollars, of which the cross-border e-commerce transactions amounted to 4.312 billion U.S. dollars. By 2016, the total export value of Yiwu reached 23.04 billion U.S. dollars, cross-border e-commerce e-commerce transactions has reached USD 8.521 billion, compared to 2014, total export growth has nearly doubled. It can be seen that the cross-border e-commerce of Yiwu City has a rapid development stage and has great potential for development.

\subsubsection{Industrial Agglomeration Effect}

Yiwu City is a pilot city for the development of cross-border e-commerce in China. It is the only e-commerce demonstration city approved in the country. The vigorous development of cross-border e-commerce has resulted in the formation of a cross-border e-commerce industrial park in Yiwu City. Industrial agglomeration is conducive to the formation of economies of scale, promotes the establishment and improvement of infrastructure, reduces the cost of e-commerce, and facilitates the exchange of information and the flow of people and the development of new technologies. It is conducive to forming a regional brand effect and increasing popularity.

\subsubsection{Foundation Support for Traditional Industry}

Yiwu City is famous for its small commodity production. It has a good industrial base and market share in the production of small commodities. The development of cross-border e-commerce can take advantage of its existing industrial advantages to gain advantages such as convenience and low cost in proximity to products and service resources at the place of production. With the help of the Internet platform, not only can companies sell products in a more convenient way, can also explore the international market, rely on its comparative advantages and even absolute advantages in exporting goods, it will in turn promote the re-development of traditional industries. In addition, cross-border e-commerce companies can use existing advanced facilities in the development process to avoid redundant construction and waste of resources, improve the quality of economic development, improve the efficiency of resource use, and promote the rapid and efficient development of cross-border e-commerce industry.

\subsection{Disadvantages}

\subsubsection{Product homogeneity is serious}

Yiwu's small commodity products are rich in variety and types, however, the degree of similarity of goods is high and the imitation is serious. Looking at the current cross-border e-commerce sales list, many businesses are mostly the same products, product homogeneity is more serious, and the lack of their own unique innovative products, this will lead to shoppers unable to attract customers for a long time and their customer loyalty is low. Secondly, under the fierce market competition conditions, lowering the cost of goods alone to maintain low prices has gradually become no longer a competitive advantage for businesses. If the status quo is maintained, it will only be eliminated by the market.

\subsubsection{The logistics system is not sound}

The current unsound logistics system in Yiwu is mainly manifested in three aspects. 1 . The delivery cycle is long. Due to cross-border purchase, goods are generally shipped overseas, and the journey is far away. Customs inspections and inspections are used to increase the logistics time. Longer logistics time will reduce consumer satisfaction. 2 . The transportation process is unstable, such as the courier's violent sorting causing internal destruction of the goods. 3. Difficulty in return caused by logistics, offshore logistics due to distance, time, customs and other factors do not support the no reason returnning, resulting in consumers can not return the problem goods, affecting consumer experience.

\subsubsection{Talent shortage}

The rapid development of cross-border e-commerce requires the support of human resources. However, Yiwu City, as a county-level city, faced great difficulties in obtaining talent resources. The demand for cross-border e-commerce talents is huge and the supply is insufficient. The lack of 
systematic training plan for talents in Yiwu city is not of high quality. The lack of a unified platform for support, together with the loss of talents, has caused Yiwu City to face the dilemma of talent shortage and hinder the further development of cross-border e-commerce.

\subsection{Opportunities}

\subsubsection{Rapidly Increasing Online Shopping Population}

Since the beginning of reform and opening up, China's national income has been continuously rising, and people's demand for consumption has also gradually increased. In 2017, the global online retail transaction volume reached 2.304 trillion U.S. dollars, an increase of $24.8 \%$ year-on-year, accounting for $10.2 \%$ of the total global retail sales from $8.6 \%$ in 2016 . Among them, China is the world's largest and most dynamic e-commerce market. In 2017, total e-commerce transactions reached 29.2 trillion yuan, an increase of $11.7 \%$ year-on-year. B2C sales and online consumer purchases ranked first in the world.

\subsubsection{The Support of Government Policy}

China has published " The Belt and Road " plan, which provides a good opportunity for the development of cross-border e-commerce in Yiwu City. The State Council promulgated the policy document to approve the establishment of a comprehensive experimental zone for cross-border e-commerce in Yiwu City. The General Administration of Customs, the National Development and Reform Commission, and the Ministry of Commerce have issued relevant policies. At the same time, Zhejiang Province, Yiwu City, introduced policies to speed up the construction of cross-border e-commerce development demonstration zones, and provide generous incentive subsidies for e-commerce parks, e-commerce office buildings, e-commerce companies and other related industrial chains.

\subsection{Threat}

\subsubsection{Cross-border e-commerce consumption}

Consumers face many problems in cross-border consumption, among which credit issues are most prominent due to information asymmetry, poor transaction time, and network anonymity. The performance is as follows: the seller loses his faith, the logistics party loses credibility, etc. Besides, there are also difficulties in unification of commodity standards, more complaints of false bills, weak awareness of intellectual property rights, serious overbail clauses, and evaluation of information security issues. Not only does harm to the interests of consumers, but also are detrimental to the further development of cross-border e-commerce. This is a problem that must be faced by Yiwu City and even China's cross-border e-commerce.

\subsubsection{Trade, Tariff Barriers}

In the process of cross-border trade, it is inevitable that trade frictions, barriers, trade wars, and tariff warfare will raise the price of domestic seaborne commodities, harm consumer interests, affect consumer demand for overseas shopping, and hinder the development of cross-border e-commerce. Illegal acts such as smuggling may be detrimental to China's economic development and social stability. In addition, anti-dumping measures in some countries also threaten the foreign trade of cross-border e-commerce.

\subsubsection{Cross-border payment issues}

At present, the management of the capital of cross-border e-commerce companies is generally based on general trade management. However, in practice, it is difficult to realize payment collection and payment in accordance with general trade regulations. In actual transactions, cross-border e-commerce realizes the collection and payment of funds through the offshore accounts, personal spin-offs, underground banks and other channels. The lack of regular payment systems and channels has led to the insecurity of cross-border revenue and expenditure funds, threatening the company's cash flow and operating stability. 


\section{Summary}

In summary, under the "Belt and Road" background, cross-border e-commerce in Yiwu has great opportunities and potential for development. Despite the initial industry scale supported by government policies and the unique industrial advantages, it is still in the early stage of development, facing with many disadvantages and many threats, however, the cross-border e-commerce in Yiwu lacks the ability to solve these problems. The top priority is to develop related technologies, cultivate professionals, improve infrastructure, improve innovation capabilities, and enhance the ability to respond to risks and challenges.

\section{References}

[1] ZHU Qisong, ZHU Huiting, The SWOT Analysis of the Development of Cross-border E-commerce in Chongqing under the Background of Internet Plus_- Taking Chongqing as an example, Journal of Sichuan University of Science \& Engineering (Social Sciences Edition), 2016,31(05):73-82.

[2] CHENG Chunpeng, A SWOT Analysis of Cross-border E-commerce Development in Yiwu, Zhejiang, Journal of Commercial Economics, 2017(21):73-76.

[3] XU Jinbo. Research on the Development Policy of Cross-border E-Commerce in Industrial Clusters_-A Case Study of Yiwu City, Zhejiang Province. Journal of Commercial Economics,2017(21):73-76.

[4] GAO Ge, LIU Xianyu. Problems and Countermeasures of Cross-Border E-Commerce Development in Yiwu City, Zhejiang Province. Economic Outlook the Bohai Sea, 2018(02):118-119.

[5] GONG Wenlong, WU Shenlan. Cross-border E-commerce Talent Cultivation under the Background of Economic Transformation and Upgrade of Yiwu. Business Economy, 2017(04):89-90+96. 